\title{
Small and Medium Enterprises in the Sustainable Supply Chain: A Review
}

\author{
Barbara Fetter ${ }^{1 *}$ \\ ${ }^{1}$ Department of Environmental Economics, Faculty of Economic and Social Sciences, Budapest University of Technology and \\ Economics, H-1117 Budapest, Magyar tudósok körútja 2, Hungary \\ * Corresponding author, e-mail: fetter.barbara@mail.bme.hu
}

Received: 22 May 2018, Accepted: 04 December 2018, Published online: 07 August 2019

\begin{abstract}
The aim of this paper is to provide a literature review and a summary of the role of small- and medium sized enterprises (SME) in greenand sustainable supply chains using a comprehensive review of the literature. After introducing the most important notions relating to sustainable supply chains and the survey methodology, a detailed analysis of scientific publications describing various issues related to SMEs and their role in green/sustainable supply chains will be presented. Results show the most important focus areas addressed and methodologies used in the literature, as well as a list of potential research questions still unanswered in this important topic.
\end{abstract}

Keywords

SME, sustainable supply chain, literature review

\section{Introduction}

Sustainable development has gradually entered the agenda of business organizations from the end of the 1980's (largely influenced by the Brundtland Report, “Our Common Future" published in 1987 (United Nations General Assembly, 1987)) and as a result companies have undergone significant changes over the past thirty years.

In a society dominated by the global economy, the sustainability implications of industries become significant (Nousala, 2009). Companies are facing increasingly complex and rapidly changing market environments, particularly SMEs, the competitiveness of which depends more and more on the early identification of new customers and market needs (Rogalski et al., 2013). Nowadays, SMEs are characterized by an integration into global value chains, where they have to face the social and environmental requirements of their multinational customers (Jorgensen and Knudsen, 2006). As large companies make efforts to improve their environmental performance and governments pass increasingly demanding environmental regulations responding to the expectations of different social groups, SMEs must also reduce the environmental impact of their operations (Mathiyazhagan et al., 2013). The growing concern regarding the state of the natural environment has prompted manufacturing companies to adopt and apply green procurement practices in their business processes, the importance of which is underlined by the fact that supply chain management is more and more often one of the key elements of a company's competitive edge (Côté et al., 2008). The role of SMEs in global supply chains is important not only from an economic, but also from an environmental point of view. Global supply chains can also ensure that SMEs comply with environmental regulations. If large customers define environmental criteria during their purchasing activities, then SMEs also need to meet these requirements to succeed on the market (Nulkar, 2014). The green supply chain requires coordinated action on behalf of participating companies from different countries (Liu et al., 2014). But the greening of the supply chain does not only pose a threat to SMEs, but also provides them with opportunities in their national and international markets (Frey et al., 2013).

From another perspective, SMEs can also be seen as bottlenecks influencing the environmental performance of an entire supply chain as a result of their lack of information, infrastructure and expertise (Ramakrishnan et al., 2015). SMEs often lack the capabilities and resources to contribute to a green supply chain (Lee and Klassen, 2008).

The scientific literature has dealt with the role of SMEs in green or sustainable supply chains and numerous articles have been produced on this subject since the second half of the 1990s. The aim of this paper is to summarize the 
situation of small- and medium enterprises (SME) in the green- and sustainable supply chain (GSC, SSC) in light of a review of the literature. In the first part of the paper I will shortly introduce the most important concepts relating to the topic, which have also served as the basis of the search for the relevant literature. Then I introduce the search method used and the findings of the review of the literature including the most important focus topics covered, the evolution of research questions and the methodologies used. Finally I will identify potential research questions to be addressed by the experts of the field in the next couple of years.

\section{Conceptual overview and methodology}

The literature agrees that cooperation along the supply chain has a positive impact on the competitiveness of companies along the supply chain (Cigolini et al., 2004). The definitions of supply chains use two different - often confused -interpretations: one approaching the chain as a group of organizations and the other as a complex process (Gelei, 2010; Gelei and Dobos, 2014).

On the one hand, the supply chain can be seen as a group of companies through which raw materials and final products flow (La Londe and Masters, 1994). According to Lambert et al. (1998), the supply chain is a group of companies that jointly sell products or services. As reported by Gelei et al. (2011) the supply chain can be interpreted along the flow of materials among affiliated companies. Furthermore, Mentzer et al. (2001) define the concept of supply chain that three or more organizations or groups of individuals directly involved in the inward and outward flow of products, services, funds, information from the procurement to the consumer. Pursuant to the process based interpretation, a supply chain is a series of economic activities that are connected vertically and across corporate boundaries in order to satisfy consumer demand (Chikán, 2008). In line with other definitions, the supply chain is a network of organizations that incorporate both inward and outward connections, different processes and activities that add value to the product or service delivered to the final consumer (Christopher, 1992).

Supply Chain Management aims to increase competitiveness and improve cooperation between partners and harmonize consumer expectations and material flows of suppliers, which can help balance a range of contradictory goals such as high customer service levels, low inventory levels and unit costs (Stevens, 1989). Supply chains are usually organized around one central company, which is typically the engine of the operations along the chain (Gelei, 2003).
Supply Chain Management (SCM) definitions can be differentiated whether their authors describe supply chain management as a management philosophy or rather focus on specific activities to be implemented in practice. The management philosophy approach seeks the opportunity to coordinate and approach operational and strategic capabilities within companies and among companies in order to get a unified and strong market share. SCM as an integrative driving philosophy directs members of the supply chain to develop innovative solutions to create a unique customer value. In this regard, it is essential to share and serve consumer expectations and values as a common goal (Gelei and Nagy, 2005). Strategic integration is needed in supply chain management to avoid overlaps and allow members to become more efficient at lower cost levels. Mutual risk and profit sharing creates a competitive advantage. Risk and profit sharing reflects the commitment of the parties, which can only be achieved within the framework of long-term cooperation. Supply chain operations can only be successful if, in addition to coordinated processes, chain members have the same goals and focus on customer service. Stabilizing these key elements is essential not only for the process but for the strategic integration among members as well (Nagy, 2006).

Green Supply Chain Management can be defined as integrating environmental aspects into supply chain management, including those related to product design, purchasing and the selection of suppliers, manufacturing processes, end-product delivery, the use of products and their end of life disposal (Che, 2010). While green supply chain management deals with products and services that reduce health and environmental impacts compared to similar products and services used for the same purpose, sustainable supply chains also integrate social aspects into the supply chain. While "green" supply chains consider only impacts of products and services on the natural environment, sustainability is a much wider term that addresses the consequences of longer-term use of products and services and considers social and financial impacts as well (Gelei and Nagy, 2005). In the present study, I analyse both the green supply chain and the sustainable supply chain at small and medium-sized companies.

Using the concepts introduced above, a review of the literature was carried out using the Scopus database to identify relevant scientific work. The search terms used are introduced in Table 1 along with the number of hits in the database. 
Table 1 Searching methods

\begin{tabular}{|c|c|c|c|c|}
\hline Search no. & Search term 1 & Search term 2 & Search term 3 & Hits in: article title/abstract/keyword \\
\hline 1 & green & SME & supply chain & 24 \\
\hline 2 & sustainable & SME & supply chain & 60 \\
\hline 3 & green & Small and medium enterprise & supply chain & 28 \\
\hline 4 & sustainable & Small and medium enterprise & supply chain & 44 \\
\hline 5 & green & SME & purchasing & 4 \\
\hline 6 & sustainable & SME & purchasing & 2 \\
\hline 7 & green & Small and medium enterprise & purchasing & 2 \\
\hline 8 & sustainable & Small and medium enterprise & purchasing & 3 \\
\hline 9 & green & SME & procurement & 5 \\
\hline 10 & sustainable & SME & procurement & 8 \\
\hline 11 & green & Small and medium enterprise & procurement & 6 \\
\hline 12 & sustainable & Small and medium enterprise & procurement & 11 \\
\hline
\end{tabular}

Searching in the title, keywords and abstracts of scientific publications, the 12 different searches resulted in 197 articles. Removing the duplicates from the result lists created the final sample consisting of 139 articles.

Most of the studies were published within the domain of "business, management and accounting", but several articles have been published within the topic area of engineering and environmental science.

The studies in the examined sample were primarily generated in the following countries: United Kingdom, India, Malaysia, Italy, United States, China, Indonesia, Poland, Taiwan, Spain, Brazil, Canada, Denmark, France and Netherlands.

\section{An analysis of the literature}

\subsection{Research outlets}

The Journal of Cleaner Production as an outlet of research publications is dominating the field with a total of 16 articles from 2008 to the present. It is worth noting that 6 out of the 10 most frequently quoted articles were also published in this journal (Mathiyazhagan et al., 2013; Klewitz and Hansen, 2014; Moore and Manring, 2009; Côté et al., 2008; Santolaria et al., 2011). The second journal publishing most of the articles dealing with the connection of GSC, SSC and SMEs is the Supply Chain Management Journal. The first article was published in 2006 looking at a qualitative case study of Scottish companies. Articles in both the Supply Chain Management Journal and the Journal of Cleaner Production focus on SMEs primarily from the viewpoint of the area of business, management and accounting.

According to Scopus, the most frequently cited article (213 citations) in the research topic is Lee and
Klassen's (2008) article titled "Drivers and Enablers That Foster Environmental Management Capabilities in Small and Medium-Sized Suppliers in Supply Chains". This article examined the suppliers of two large companies within a case study and explored factors that help support environmental issues in small and medium-sized enterprises. The second most frequently cited article (with 169 citations) is Mathiyazhagan et al. (2013): "An ISM Approach for the Barrier Analysis in Implementing Green Supply Chain Management". Klewitz and Hansen (2014) approached in theirs article in 2014 "The Sustainability-oriented Innovation of SMEs: A Systematic Review" (137 citations) SMEs from the aspect of sustainable business models and highlighted the importance of eco-innovation and sustainability-oriented innovation (SOI). His main theoretical contribution was to develop an integrated framework for SMEs' sustainability-oriented innovation. Moore and Manring (2009) analyzed the importance of using fast-growing communication technologies and the essential role of internal incentive forces in his study on sustainable strategies for small and medium-sized enterprises for sustainability and increased value creation in 2009. Following this Lee et al. (2012) examined the role of GSCM in SME business performance through a questionnaire survey in South Korea, in his article on green supply chain management and organizational performance in 2012. In study of Walkerand Preuss (2008) „Fostering sustainability through sourcing from small businesses: public sector perspectives" explores opportunities for promoting sustainable development through the procurement of small and medium-sized enterprises by the public sector. Jorgensen and Knudsen (2006) examined the concept of governance in the global value chains from a SME point 
of view in his article "Sustainable competitiveness in global value chains: how do small Danish companies behave?" in 2006. Camarinha-Matos et al. (2008) looked at the organizational sustainability aspect of the basics and mechanisms for creating advanced network-based industries in his "Ecolead And Cno Base Concepts" in 2008. According to the article "Influences, Practices and Opportunities for Environmental Supply Chain Management in Nova Scotia SMEs" written by Côté et al. (2008), in 2008, GSCM's most restrictive factors are the lack of funding and resource allocation problems. Santolaria (2011) explained sustainability as one of the most crucial factors in corporate innovation in his article "Eco-design in innovation driven companies: perception, predictions and the main drivers of integration. The Spanish example" in 2011.

\subsection{Focus areas}

Green supply chains were first mentioned in the literature in the middle of the 1990's (Sarkis et al., 1996; Handfield et al., 1997) but these early publications do not reflect on the role of SMEs in green supply chains. The first studies describing sustainable supply chains were published in 2000 (see Nagel, 2000: "Environmental supply-chain management versus green procurement in the scope of a business and leadership perspective" and Zhou et al., 2000: "Supply chain optimization of continuous process industries with sustainability considerations"), but these also lack an SME perspective.

The 1990s show a significant increase in the literature regarding the environmental practices of SMEs, but most of the research aimed at either concrete technological solutions or their application in small and medium enterprises or took the perspective of cleaner production and environmental management systems. In 2004 Bevis (2004) and Ratchev and Pawar (2004) illustrated the importance of knowledge management and lack of know-how at SMEs, while Macpherson et al. (2005) emphasized the importance of infrastructure development for SMEs. In the middle of the 2000's several studies examined the importance of knowledge management to build on competitive advantage, while supply chain strategies, such as the load sharing initiative, supply chain collaborations and transport sharing, gained more emphasis as well (Martin et al., 2006; Wagner and Alderdice, 2006). Green approaches, organizational developments to reduce life cycle impacts and improve environmental performance and new and more accurate sustainability indicators for SMEs were the main topics discussed in 2007 (Rao, 2007; Beynon-Davies et al.,
2007; Woolman and Veshagh, 2007; Bridges and Curran, 2007). Later, the examination of barriers has gained more and more importance in the context of case studies. A significant number of studies deal with the motivation factors in SMEs, as well as new business models available to them, while questions of infrastructure development, opportunities for future digital commerce provided by the Internet were also raised as other relevant factors in the literature. Research has mainly emphasized the importance of IT infrastructure to engage in supply chains, while articles mostly analyzed the environmental behaviors of SMEs, the need to create a sustainable business cycle and the development of new techniques for the selection of suppliers. Diófási-Kovács and Valkó (2017) dealt with the tools and strategies of green procurement from the point of view of Hungarian public and private organizations. More recently CSR and the approaches of eco-innovation, eco-efficiency and eco-design, as well as the infrastructure and technology aspects of Industry 4.0 have been considered by the authors of relevant research papers.

As presented above, the most important focus areas of scientific research in the field are as follows: motivational factors and barriers to the participation of SMEs, business models supporting green supply chains, Environmental Management Systems, Corporate Social Responsibility and the use of information and communication technologies. The issues of related to CSR (Ayuso et al., 2013; Delchet-Cochet and Azhar-Arnal, 2017; Musso and Risso, 2015) dealt with the integration of CSR into small and medium-sized companies and looked at the key factors of CSR adoption, CSR tools developed and applied by SMEs, and the use of CSR tools in SMEs developed by large companies (Ayuso et al., 2013; Delchet-Cochet and Azhar-Arnal, 2017; Lin and Lan, 2013; Musso and Risso, 2015). Results show that small and medium-sized companies can use the tools of CSR with positive effects on their operations.

Evidence shows that ISO certification also has a positive effect on the supply chain practices of SMEs. According to Rao (2007) ISO-certified SMEs perform better both in environmental and economic terms, while Jia et al. (2015) highlighted that ISO14000 certification practices play a decisive role in SSCM practice. However, similarly to the introduction of CSR, Ramakrishnan et al. (2015) claim that ISO14001 is typically used by SMEs as a result of external pressure and a need to comply with government standards, but its positive returns can be measured as well.

Logistics is considered as a field needing infrastructure and technology development but having significant 
strategic importance. The main issue of logistics is primarily addressed with its regard to government and policy regulation, but backlog logistics and the expected logistical effects of industry 4.0 are also considered as important factors in the life of supply chains.

Another critical issue is the development of communication technology and infrastructure along the green supply chain, especially for SMEs, if they want to enter global supply chains. The importance of infrastructure and communication technology is emphasized by several authors (Fuza et al., 2015; Iffah et al., 2015; Jevtic et al., 2013; Macpherson et al., 2005; Singh et al., 2010). The authors agree on the importance of knowledge management in green and sustainable supply chains and identify them as one of the main barriers to the participation of SMEs. Another obstacle identified relates to the lack of funding. These problems will probably be exacerbated by the expansion of activities resulted by the $4^{\text {th }}$ industrial revolution. Limited capacities and resources available to SMEs also reduce the positive impact of effective environmental management along the supply chain.

Financial constraint faced by SMEs can be tackled by the development of various synergistic, supportive customer-supplier relationships between large companies and SMEs. Motivation factors include government incentives and support programs as well as the possibility to access new markets. To summarize the relevant studies published on the subject to date it can be concluded that over the past ten years considerable emphasis has been on the examination and optimization of the integration of SMEs into supply chains by developing new structural, value network and business models. However, evidence shows clearly that the main obstacles identified in the literature still persist (see e.g. Vörösmarty and Dobos (2013) addressing the motivation factors and ethical issues relating to green procurement).

I expected a significant difference between the studies in the examined regions, so my sample was broken down separately for the developed and developing regions. However, studies turned out to focus on the same issues in both of these regions: the importance of developing knowledge management, the necessity of the infrastructure, financing shortages, developing new supply chain strategies and new business models. One possible reason for the similarity may be that SMEs face similar difficulties worldwide when joining global supply chains. Since joining global supply chains is the primary goal, culture as a determining factor is less significant.

\subsection{Methods used}

Research output took the form of journal articles from the second half of the 1990's, while conference papers started to grow only after 2007. First, case studies dealt with sustainability practices as long-term investment opportunities (Cambra-Fierro and Ruiz-Benítez, 2011) then load sharing as a supply strategy for the sustainable growth of SMEs became the center of focus (Wagner and Alderdice, 2006). The survey method has only been used since 2012 since when articles using such an approach appear every year.

Case studies are usually concentrated around the development of a new method, business model or sustainability indicator that aims to improve the performance of a given SME. In addition, several case studies have been devoted to the study of knowledge management, IT structure and logistics, and the relationship between supply chain actors. Case studies have been typically prepared in Switzerland, Sweden, Spain, Italy, Scotland, the USA, and the United Kingdom.

While case studies consistently focus on practices in developing countries, questionnaire surveys focus developing countries (Korea, Taiwan, Malaysia, China, Nigeria, India). The main topics of questionnaire surveys are the role of GSCM in business and environmental performance, SME motivation for GSCM acceptance, assessment of information and communication technology, identification of innovation links, development of new sustainable development indicators and building existing organizational models.

Another important branch of studies takes a sectoral approach. Studies in the steel and mechanical industry (including the automotive industry) initially focused on the crucial importance of knowledge management, including a lack of expertise (Bevis, 2004, surveyed region: United Kingdom), while another study looked at the situation of automotive SMEs in the green supply chain five years later, whereby according to the author new business models were needed for SMEs to survive (Nousala, 2009, Australia). Following this Liu et al. (2014) analyzed the role of GSCM in the environmental performance in Taiwan. He found that SMEs mostly used reactive approaches to respond to external pressures. Peruzzini et al. (2014) worked on the definition of a new and unique product life cycle. He considered limited management and business knowledge, lack of financing, and exposure to cumbersome regulatory and bureaucratic requirements as major obstacles in this regard. He also referred to the rapidly 
changing economic environment surrounding SMEs as a major obstacle, since if unforeseen disturbances arise, SMEs may be more sensitive than their larger counterparts. Li and Mathiyazhagan (2018) developed sustainable development indicators for the Indian automotive industry. Finally, according to Ashton et al. (2017), who examined green motivation of SMEs in 2017, most companies behave in response to green practices as internal motivation. However, these internal motivations are primarily driven by cost and competitiveness concerns rather than social responsibility. As far as the oil and natural gas industry is concerned, Araujo et al. (2008) described the importance of organizational development and the implementation of a more efficient management system that can be applied without endangering resources. Suppliers in mining- and mineral industries consider ISO14000 certification as decisive in SSCM practice for SMEs (Jia et al., 2015). Jia et al. (2015) note that environmental certification is indispensable for increasing the sustainability performance of Indian mining and mineral industries. Studies on the construction and timber industries focus primarily on eco-efficiency, the analysis of raw material suppliers (Charmondusit et al., 2014) and the development of a conceptual model for company performance that attempts to explain how GSCM performance is different from companies depending on the type of GSCM practice and the SME character (Susanty et al., 2016). Han et al.'s new model (2017) has shown that all technology determinants, namely identified in the study have a significant impact on the acceptance of greener production. Kachba and Hatakeyama (2015) highlighted significant technological failures of the textile industry SMEs, while Ashby (2016) looked at the interactions between network actors through social network theory. In the food industry, Cambra-Fierro and Ruiz-Benítez (2011) first introduced sustainability practice as a long-term investment in 2011. Little et al. (2009) highlighted the need for strengthening the available knowledge base of SMEs. Svensson and Wagner (2012) focused on the need to create a sustainable business cycle, while Tsekouropoulos et al. (2014) made an effort to develop a new organizational model responding more efficiently to the needs of consumers.

Comparing industries, it has become apparent that the biggest external pressure is exposed to the steel and automotive industries that is why most of the studies deal with these industries.

\section{Conclusion}

Examining the progress of the literature relating to green and sustainable supply chain management in general, it can be observed that SMEs face similar challenges to the multinational company. Current focus areas and topics for further research for both SMEs and multinational corporations include the developments of industry 4.0, technological innovations and logistics. The information needs to be provided by appropriate information technologies are vital. Our understanding of logistics and warehousing should be improved since particular changes in these operations can enable organizations and their supply chains to improve their environmental and sustainability performance while staying economically viable and stable (Dubey et al., 2017). Consistent with Pagell and Wu (2009), we can conclude that sustainable supply chains can occur only through learning and innovation. Knowledge accumulated within supply chains allows supply chain members to jointly reduce innovation uncertainties, to change as a system and become more sustainable (Silvestre, 2015a; Smith and Sharicz, 2011). Supply chain members can jointly learn how to build new capabilities for innovations that help the entire supply chain to become more sustainable through learning loops (Silvestre, 2015b).

Overall, the operation of green and sustainable supply chains can be only successful if, in addition to coordinated processes, the chain members have the same goals and focuses with regard to customers. This requires a strategic integration between the participating members of the supply chain. This review of the literature demonstrated that several aspects of green and sustainable supply chains relating to SMEs have been uncovered by research to date, but still more knowledge is needed in order to foster the integration of sustainability into SME practice.

Questions to be further explored include a better understanding of the motivation factors of SMEs and how they can be influenced by environmental and economic policy, as well as how new technological innovations, including the implications of the $4^{\text {th }}$ industrial revolution can be used by SMEs to take advantage of greening supply chains.

New forms of cooperation should also be discovered, as well as the overall impacts of emerging business models, and how SMEs can implement them in their daily operations. This can be done through large scale surveys or by the close examination of best practices and the diffusion of experiences learnt from them. 


\section{References}

Araujo, R., Araujo, R. S. B., Fernades, E., Alonso, P. S. R., Machado, A. B. (2008) "Key Sucess Factors in the Brazilian O \& G Supply Chain - Sustainability and New Challenges to SME", In: $19^{\text {th }}$ World Petroleum Congress 2008: A World in Transition: Delivering Energy for Sustainable Growth, Madrid, Spain, pp. 1327.

Ashby, A. (2016) "From global to local: reshoring for sustainability", Operations Management Research, 9(3-4), pp. 75-88. https://doi.org/10.1007/s12063-016-0117-9

Ashton, W., Russell, S., Futch, E. (2017) "The adoption of green business practices among small US Midwestern manufacturing enterprises", Journal of Environmental Planning and Management, 60(12), pp. 2133-2149.

https://doi.org/10.1080/09640568.2017.1281107

Ayuso, S., Roca, M., Colomé, R. (2013) "SMEs as "transmitters" of CSR requirements in the supply chain", Supply Chain Management: An International Journal, 18(5), pp. 497-508.

https://doi.org/10.1108/SCM-04-2012-0152

Bevis, K. (2004) "Learning at work [automative college]", Manufacturing Engineer, 83(1), pp. 30-33.

https://doi.org/10.1049/me:20040106

Beynon-Davies, P., Parfett, M., Evans, C., Whittle, S. (2007) "Preparing SME Suppliers for Sustainable Local Authority eProcurement", In: $20^{\text {th }}$ Bled eConference - eMergence: Merging and Emerging Technologies, Processes, and Institutions, Bled, Slovenia, pp. 471-484.

Bridges, J. S., Curran, M. A. (2007) "Metrics: Essential for environmental decision-making and sustainability", In: $100^{\text {th }}$ Annual Conference and Exhibition of the Air and Waste Management Association 2007, ACE 2007, Pittsburgh, Pennsylvania, pp. 1565-1574.

Camarinha-Matos, L. M., Afsarmanesh, H., Ollus, M. (2008) "Ecolead And Cno Base Concepts", In: Camarinha-Matos, L. M., Afsarmanesh, H., Ollus, M. (eds.) Methods and Tools for Collaborative Networked Organizations, Springer, Boston, MA, USA, pp. 3-32. https://doi.org/10.1007/978-0-387-79424-2_1

Cambra-Fierro, J., Ruiz-Benítez, R. (2003) "Sustainable business practices in Spain: A two-case study", European Business Review, 23(4), pp. 401-412.

https://doi.org/10.1108/09555341111145780

Charmondusit, K., Phatarachaisakul, S., Prasertpong, P. (2014) "The quantitative eco-efficiency measurement for small and medium enterprise: a case study of wooden toy industry", Clean Technologies and Environmental Policy, 16(5), pp. 935-945. https://doi.org/10.1007/s10098-013-0693-4

Che, Z. H. (2010) "Using fuzzy analytic hierarchy process and particle swarm optimisation for balanced and defective supply chain problems considering WEEE / RoHS directives", International Journal of Production Research, 48(11), pp. 3355-3381. https://doi.org/10.1080/00207540802702080

Chikán, A. (2008) "Vállalatgazdaságtan" (Business Economic), Aula Kiadó, Budapest, Hungary. (in Hungarian)

Cigolini, R., Cozzi, M., Perona M. (2004) "A new framework for supply chain management: Conceptual model and empirical test", International Journal of Operations and Production Management, 24(1), pp. 7-41.

https://oi.org/10.1108/01443570410510979
Christopher, M. (1992) "Logistics and Supply Chain Management", London, Pitman Publishing, London, UK.

Côté, R. P., Lopez, J., Marche, S., Perron, G. M., Wright, R. (2008) "Influences, practices and opportunities for environmental supply chain management in Nova Scotia SMEs", Journal of Cleaner Production, 16(15), pp. 1561-1570. https://doi.org/10.1016/j.jclepro.2008.04.022

Delchet-Cochet, K., Azhar-Arnal, J. (2017) "SMEs' suppliers' practices and contractors' expectations on CSR management tools: the gap", International Journal of Sustainable Development (IJSD), 20(3-4), pp. $250-268$. https://doi.org/10.1504/IJSD.2017.089997

Diófási-Kovács, O., Valkó, L. (2017) "Transition to Green Economy: Green Procurement Implementation Strategies Experiences from Hungarian Public and Private Organizations", In: Leal Filho, W., Pociovalisteanu, D. M., Al-Amin, A. (eds.) Sustainable Economic Development: Green Economy and Green Growth, World Sustainability Series, Springer, Cham, Switzerland, pp. 243-257. https://doi.org/10.1007/978-3-319-45081-0_14

Dubey, R., Gunasekaran, A., Papadopoulos, T., Childe, S. J., Shibin, K. T., Wamba, S. F. (2017) "Sustainable supply chain management: framework and further research directions", Journal of Cleaner Production, 142(2), pp. 1119-1130.

https://doi.org/10.1016/j.jclepro.2016.03.117

Frey, M., Iraldo, F., Testa, F. (2013) "The determinants of innovation in green supply chains: evidence from an Italian sectoral study", R \& D Management, 43(4), pp. 352-364.

https://doi.org/10.1111/radm.12020

Fuza, Z. I. M., Ismail, H. N., Isa, S. M. (2015) "Importance of Information Communication Technologies (ICT) among tour operators in Malaysia", In: $3^{\text {rd }}$ International Congress on Interdisciplinary Behavior and Social Sciences, ICIBSoS 2014, Bali, Indonesia, pp. $255-261$.

Gelei, A. (2003) "Az ellátási lánc típusai és menedzsment kérdései" (Supply Chain Types and Management Issues), Vezetéstudomány Budapest Management Review, 34(7-8), pp. 24-34. (in Hungarian)

Gelei, A. (2010) "Az ellátási lánc menedzsmentje" (Supply Chain Management), In: Czakó, E., Reszegi, L. (eds.) Nemzetközi vállalatgazdaságtan (International Business Economics), Alinea Kiadó, Budapest, Hungary. (in Hungarian)

Gelei, A., Dobos, I. (2014) "Modeling Life Cycles of Supply Chain Relationships", Periodica Polytechnica Social and Management Sciences, 22(1), pp. 1-12. https://doi.org/10.3311/PPso.7424

Gelei, A., Dobos, I., Nagy, J. (2011) "Üzleti kapcsolatok beágyazottsága a magyar gazdaságban" (Heaviness of the Hungarian business relationships), Vezetéstudomány - Budapest Management Review, 42(1), pp. 17-30. (in Hungarian)

Gelei, A., Nagy, J. (2005) "Versenyképesség az autóipari ellátási láncban: A vevői érték és dimenziói az egyes beszállító típusok esetében" (Competitiveness in the automotive supply chain: Customer value and dimensions for each type of supplier), Vezetéstudomány - Budapest Management Review, 36(3), pp. 10-20. (in Hungarian) 
Han, Y., Skibniewski, M. J., Wang, L. (2017) "A Market Equilibrium Supply Chain Model for Supporting Self-Manufacturing or Outsourcing Decisions in Prefabricated Construction", Sustainability, 9(11), article ID: 2069. https://doi.org/10.3390/su9112069

Handfield, R. B., Walton, S. V., Seegers, L. K., Melnyk, S. A. (1997) "'Green' value chain practices in the furniture industry", Journal of Operations Management, 15(4), pp. 293-315. https://doi.org/10.1016/S0272-6963(97)00004-1

Iffah, M. F. Z., Hairul, N. I., Sulaiha, M. I. (2015) "Tour Operators Malaysia: Virtue of Adapting ICT Changes Towards Business Resilience", Advanced Science Letters, 21(6), pp. 1650-1654. https://doi.org/10.1166/asl.2015.6124

Jevtic, B., Dedjanski, S., Beslac, M., Grozdanic, R., Damnjanovic, A. (2013) "SME technology capacity building for competitiveness and export-Evidence from balkan countries", Metalurgia International, 18(4), pp. 162-170.

Jia, P., Diabat, A., Mathiyazhagan, K. (2015) "Analyzing the SSCM practices in the mining and mineral industry by ISM approach", Resources Policy, 46(1), pp. 76-85. https://doi.org/10.1016/j.resourpol.2014.04.004

Jorgensen, A. L., Knudsen, J. S. (2006) "Sustainable competitiveness in global value chains: how do small Danish firms behave?", Corporate Governance: The International Journal of Business in Society, 6(4), pp. 449-462.

https://doi.org/10.1108/14720700610689568

Kachba, Y. R., Hatakeyama, K. (2015) "Competence for Product Development Management in Clothing Firms", In: $24^{\text {th }}$ International Association for Management of Technology Conference (IAMOT 2015): Technology, Innovation and Management for Sustainable Growth, Cape Town, South Africa, pp. 1863-1876.

Klewitz, J., Hansen, E. G. (2014) "Sustainability-oriented innovation of SMEs: a systematic review", Journal of Cleaner Production, 65, pp. 57-75.

https://doi.org/10.1016/j.jclepro.2013.07.017

Lambert, D. M., Stock, J. R., Ellram, L. M. (1998) "Fundamentals of Logistics Management", Irwin/McGraw-Hill, Boston, MA, USA.

La Londe, B. J., Masters, J. M. (1994) "Emerging Logistics Strategies: Blueprints for the Next Century", International Journal of Physical Distribution and Logistics Management, 24(7), pp. 35-47. https://doi.org/10.1108/09600039410070975

Lee, S. M., Kim, S. T., Choi, D. (2012) "Green supply chain management and organizational performance", Industrial Management and Data Systems, 112(8), pp. 1148-1180. https://doi.org/10.1108/02635571211264609

Lee, S.-Y., Klassen, R. D. (2008) "Drivers and Enablers That Foster Environmental Management Capabilities in Small- and MediumSized Suppliers in Supply Chains", Production and Operations Management, 17(6), pp. 573-586.

https://doi.org/10.3401/poms.1080.0063

Li, Y., Mathiyazhagan, K. (2018) "Application of DEMATEL approach to identify the influential indicators towards sustainable supply chain adoption in the auto components manufacturing sector", Journal of Cleaner Production, 172, pp. 2931-2941.

https://doi.org/10.1016/j.jclepro.2017.11.120
Lin, L.-H., Lan, J.-F. (2013) "Green supply chain management for the SME automotive suppliers", International Journal of Automotive Technology and Management (IJATM), 13(4), pp. 372-390. https://doi.org/10.1504/IJATM.2013.056862

Little, D. C., Murray, F. J., Telfer, T. C., Young, J. A., Ross, L. G., Hill, B., Dalsgard, A., van den Brink, P. J., Guinée, J., Kleijn, R., Mungkung, R., Yi, Y., Min, J., Liping, L., Huanan, L., Yuan, L., Derun, Y., Phuong, N. T., Hai, T. N., Liem, P. T., Ut, V. N., Tung, V. T., Viet, T. V., Satapornvanit, K., Pongthanapanich, T., Wahab, M. A., Nowsad Alam, A. K. M., Haque, M. M., Salam, M. A., Corsin, F., Pems1, D., Allison, E., Beveridge, M. C. M., Karunasagar, I., Subasinghe, R., Kaiser, M., Sveinson Haugen, A., Ponte, S. (2009) "Sustaining ethical trade in farmed aquatic products between Asia and the EU", In: Millar, K., Hobson West, P., Nerlich, B. (eds.) Ethical futures: bioscience and food horizons, Wageningen Academic, Wageningen, The Netherlands, pp. 226-231. https://doi.org/10.3920/978-90-8686-673-1

Liu, C.-M., Vazquez-Brust, D. A., Sarkis, J. (2014) "The Roles of First and Second Tier Suppliers in Greening International Supply Chains", In: Vazquez-Brust, D., Sarkis, J., Cordeiro, J. (eds.) Collaboration for Sustainability and Innovation: A Role for Sustainability Driven by the Global South?: A Cross-Border, Multi-Stakeholder Perspective, Greening of Industry Networks Studies, Vol. 3, Springer, Dordrecht, The Netherlands, pp. 63-85. https://doi.org/10.1007/978-94-007-7633-3_4

Macpherson, A., Jones, O., Zhang, M. (2005) "Virtual reality and innovation networks: opportunity exploitation in dynamic SMEs", International Journal of Technology Management (IJTM), 30(1-2), pp. 49-66. https://doi.org/10.1504/IJTM.2005.006345

Martin, V., Basnet, C., Childerhouse, P., Foulds, L. (2006) "Knowledge Management for the Sustainable Supply Chain: A Literature Review", In: $7^{\text {th }}$ European Conference on Knowledge Management, ECKM 2006, Budapest, Hungary, pp. 302-309.

Mathiyazhagan, K., Govindan, K., NoorulHaq, A., Geng, Y. (2013) "An ISM approach for the barrier analysis in implementing green supply chain management", Journal of Cleaner Production, 47, pp. 283-297. https://doi.org/10.1016/j.jclepro.2012.10.042

Mentzer, J. T., DeWitt, W., Keebler, J. S., Min, S., Nix, N. W., Switch, C. D., Zacharia, Z. D. (2001) "Defining Supply Chain Management", Journal of Business Logistics, 22(2), pp. 1-25. https://doi.org/10.1002/j.2158-1592.2001.tb00001.x

Moore, S. B., Manring, S. L. (2009) "Strategy development in small and medium sized enterprises for sustainability and increased value creation", Journal of Cleaner Production, 17(2), pp. 276-282. https://doi.org/10.1016/j.jclepro.2008.06.004

Musso, F., Risso, M. (2015) "CSR for Retailers' Led Channel Relationships: Evidence from Italian SME Manufacturers", In: Human Rights and Ethics: Concepts, Methodologies, Tools, and Applications, IGI Global, Hershey, PA, USA, pp. 778-794. https://doi.org/10.4018/978-1-4666-6433-3.ch043

Nagel, M. H. (2000) "Environmental supply-chain management versus green procurement in the scope of a business and leadership perspective", In: International Symposium on Electronics and the Environment, ISEE 2000, San Francisco, CA, USA, pp. 219-224. https://doi.org/10.1109/ISEE.2000.857652 
Nagy, J. (2006) "Attitude of Hungarian companies to the concept of supply chain management", presented at $15^{\text {th }}$ Annual IPSERA Conference, San Diego, USA, April 6-8, 2006.

Nousala, S. (2009) "The Sustainable Development of Industry Clusters: Emergent Knowledge Networks and Socio Complex Adaptive Systems", In: The $13^{\text {th }}$ World Multi-Conference on Systemics, Cybernetics and Informatics, Jointly with the $15^{\text {th }}$ International Conference on Information Systems Analysis and Synthesis, WMSCI 2009 - ISAS 2009, Orlando, FL, USA, pp. 161-166.

Nulkar, G. (2014) "Does environmental sustainability matter to small and medium enterprises? Empirical evidence from India", International Journal of Environmental Studies, 71(4), pp. 481-489. https://doi.org/10.1080/00207233.2014.924304

OECD, European Bank for Reconstruction and Development, European Training Foundation, European Union (2012) "SME Policy Index: Western Balkans and Turkey 2012: Progress in the Implementation of the Small Business Act for Europe", OECD, Paris, France. https://doi.org/10.1787/9789264178861-en

Offei, I., Kissi, E., Badu, E. (2016) "Public procurement policies and strategies for capacity building of SME construction firms in Ghana", International Journal of Procurement Management (IJPM), 9(4), pp. 455-472.

https://doi.org/10.1504/IJPM.2016.077705

O’Keeffe, J. M., Gilmour, D., Simpson, E. (2016) "A network approach to overcoming barriers to market engagement for SMEs in energy efficiency initiatives such as the Green Deal", Energy Policy, 97, pp. 582-590.

https://doi.org/10.1016/j.enpol.2016.08.006

Pagell, M., Wu, Z. (2009) "Building a More Complete Theory of Sustainable Supply Chain Management Using Case Studies of 10 Exemplars", Journal of Supply Chain Management, 45(2), pp. 37-56. https://doi.org/10.1111/j.1745-493X.2009.03162.x

Peruzzini, M., Marilungo, E., Germani, M. (2014) "Functional and Ecosystem Requirements to Design Sustainable Product-Service", In: Cha, J., Chou, S.-Y., Stjepandić, J., Curran, R., Xu, W. (eds.) Moving Integrated Product Development to Service Clouds in the Global Economy, Advances in Transdisciplinary Engineering, [e-book] IOS Press, Amsterdam, The Netherlands, pp. 768-777. https://doi.org/10.3233/978-1-61499-440-4-768

Ramakrishnan, P., Haron, H., Goh, Y.-N. (2015) "Factors Influencing Green Purchasing Adoption for Small and Medium Enterprises (SMEs) in Malaysia", International Journal of Business and Society, 16(1), pp. 39-56.

Rao, P. (2007) "Greening of the Supply Chain: An Empirical Study for SMES in the Philippine Context", Journal of Asia Business Studies, 1(2), pp. 55-66. https://doi.org/10.1108/15587890780001296

Ratchev, S., Pawar, K. S. (2004) "Critical company assessment and advisory support for introduction of concurrent engineering practices", International Journal of Business Performance Management, 6(1), pp. 69-87.

Rogalski, S., Wicaksono, H., Krahtov, K. (2013) "Resource-Efficient Production Planning through Flexibility Measurements in Value Creation Systems", In: Prabhu, V., Taisch, M., Kiritsis, D. (eds.) Advances in Production Management Systems. Sustainable
Production and Service Supply Chains. APMS 2013. IFIP Advances in Information and Communication Technology, Vol. 414, Springer, Berlin, Heidelberg, Germany, pp. 119-126. https://doi.org/10.1007/978-3-642-41266-0_15

Santolaria, M., Oliver-Solà, J., Gasol, C. M., Morales-Pinzón, T., Rieradevall, J. (2011) "Eco-design in innovation driven companies: perception, predictions and the main drivers of integration. The Spanish example", Journal of Cleaner Production, 19(12), pp. $1315-1323$. https://doi.org/10.1016/j.jclepro.2011.03.009

Sarkis, J., Nehman, G., Priest, J. (1996) "A Systemic Evaluation Model for Environmentally Conscious Business Practices and Strategy", In: 1996 International Symposium on Electronics and the Environment, ISEE-1996, Dallas, TX, USA, pp. 281-286. https://doi.org/10.1109/ISEE.1996.501892

Silvestre, B. S. (2015a) "A hard nut to crack! Implementing supply chain sustainability in an emerging economy", Journal of Cleaner Production, 96, pp. 171-181.

https://doi.org/10.1016/j.jclepro.2014.01.009

Silvestre, B. S. (2015b) "Sustainable supply chain management in emerging economies: Environmental turbulence, institutional voids and sustainability trajectories", International Journal of Production Economics, 167, pp. 156-169. https://doi.org/10.1016/j.ijpe.2015.05.025

Singh, A., Narain, R., Yadav, R. C. (2010) "An exploratory study of the SCM practices and IT usage: an emerging market context", International Journal of Information Technology and Management (IJITM), 9(4), pp. 446-467. https://doi.org/10.1504/IJITM.2010.035464

Smith, P. A. C., Sharicz, C. (2011) "The shift needed for sustainability", The Learning Organization, 18(1), pp. 73-86. https://doi.org/10.1108/09696471111096019

Stevens, G. C. (1989) "Integrating the Supply Chain", International Journal of Physical Distribution and Materials Management, 19(8), pp. 3-8. https://doi.org/10.1108/EUM0000000000329

Susanty, A., Puspitasari, D., Purwaningsih, R., Winarti, R. Y. (2016) "Impact of Green Supply Chain Management Practices on Enterprise Performance in Furniture Industry: A Review for Conceptual Model", Advanced Science Letters, 22(5-6), pp. 1096-1104.

https://doi.org/10.1166/asl.2016.6760

Svensson, G., Wagner, B. (2012) "Implementation of a sustainable business cycle: the case of a Swedish dairy producer", Supply Chain Management: An International Journal, 17(1), pp. 93-97. https://doi.org/10.1108/13598541211212230

Szász, L., Matyusz, Z., Demeter, K. (2016) " A vállalatméret szerepe a termelésben - A mérési módszer hatása" (The role of company size in production-Impact of measurement method), Vezetéstudomány - Budapest Management Review, 47(2), pp. 2-11.

Tsekouropoulos, G., Vatis, S.-E., Andreopoulou, Z., Katsonis, N., Papaioannou, E. (2014) "The aspects of internet-based management, marketing, consumer's purchasing behavior and social media towards food sustainability", Rivista di Studi sulla Sostenibilita', 2014(2), pp. 207-222.

https://doi.org/10.3280/RISS2014-002013 
United Nations General Assembly (1987) "Our Common Future Report of the World Commission on Environment and Development: Our Common Future", [pdf] UNO, Available at: http://www.un-documents.net/our-common-future.pdf [Accessed: 03 December 2018]

Vörösmarty, G., Dobos, I. (2013) "Analysis of purchasing activity with discounted cash flow inventory models", Periodica Polytechnica Social and Management Sciences, 21(2), pp. 67-70. https://doi.org/10.3311/PPso.7085

Wagner, B. A., Alderdice, A. D. G. (2006) "Managing the distribution channel: the case of Scot Trout and Salmon", Supply Chain Management: An International Journal, 11(2), pp. 104-107. https://doi.org/10.1108/13598540610652474

Walker, H., Preuss, L. (2008) "Fostering sustainability through sourcing from small businesses: public sector perspectives", Journal of Cleaner Production, 16(15), pp. 1600-1609. https://doi.org/10.1016/j.jclepro.2008.04.014
Woolman, T., Veshagh, A. (2007) "Development of a Management Tool for Assessing Environmental Performance in SMEs' Design and Production", In: Takata, S., Umeda, Y. (eds) Advances in Life Cycle Engineering for Sustainable Manufacturing Businesses, Springer, London, UK, pp. 383--388. https://doi.org/10.1007/978-1-84628-935-4_66

Zhou, Z., Cheng, S., Hua, B. (2000) "Supply chain optimization of continuous process industries with sustainability considerations", Computers \& Chemical Engineering, 24(2-7), pp. 1151-1158. https://doi.org/10.1016/S0098-1354(00)00496-8 